\title{
Assessing and forecasting groundwater development costs in Sub-Saharan Africa
}

\author{
Stefanos Xenarios ${ }^{1,2 *}$ and Paul Pavelic ${ }^{3}$ \\ 'Norwegian Institute for Agricultural and Environmental Research, Norway \\ ${ }^{2}$ International Water Management Institute, East Africa \& Nile Basin Office, Addis Ababa, Ethiopia \\ ${ }^{3}$ International Water Management Institute, Southeast Asia Office, Lao P.D.R.
}

\begin{abstract}
Greater use of groundwater in Sub-Saharan Africa is a pre-requisite for improved human welfare; however, the costs associated with groundwater development are prohibitively high and poorly defined. This study identifies and disaggregates the costs of groundwater development in 11 Sub-Saharan African countries, while the cost factors that most strongly affect drilling expenditures are traced. Further, the institutional and technical constraints impeding groundwater development are also explored while a time-series analysis forecasts future drilling expenditures. The results indicate that mobilisation and demobilisation costs, together with well development costs, factors that are difficult to change, are most significantly affecting the total costs of drilling. Further, the nature of the hydrogeological formation (which is largely a site characteristic), along with the often-aged machinery (which can be controlled), are also major impediments to lowering the cost of drilling. All countries are forecasted to have a slight to considerable drilling cost decrease for the next decade which offers encouragement for future groundwater development. Greater attention to the individual cost factors and to forecasting analysis could help to design more coherent and consistent groundwater development policies in Sub-Saharan Africa.
\end{abstract}

Keywords: cost factors, groundwater drilling, forecasting analysis, Sub-Saharan Africa

\section{INTRODUCTION}

In recent years, driven by the need to improve water services and to ensure food security in Sub-Saharan Africa (SSA), there have been major efforts to enhance the level of access to groundwater through increased development (Adams et al., 2012). Although about $40 \%$ of drilling projects appear to become dysfunctional after some years (Adekile, 2012a), a remarkable number of new wells are still developed annually (Schneider, 2012). Provision of drilling technologies that are technically, economically and socially suitable is the foundation to enable such development to occur.

The economics associated with groundwater development have been investigated through various theoretical and experimental studies that focus on the various costs of drilling and equipping shallow wells and deeper boreholes (Ball 2004; Danert, 2009; Danert et al., 2010a, Fonseca et al., 2011a). The groundwater expenditures have been interpreted through different well-detailed cost factors which aim to provide an integrated economic approach to groundwater development in SSA countries (Fonseca et al., 2011a,b). However, these studies often lack a solid theoretical economic background and sufficient data, and are applied across a limited geographical coverage.

Rarely have the total costs of drilling been systematically disaggregated component-wise and compared at a cross-country level on a wide scale across SSA.

Also, the institutional and technical constraints impacting groundwater drilling efforts tend to be evaluated on a

\footnotetext{
To whom all correspondence should be addressed.

용 +47920 11809; fax: +47 78995600 ;

e-mail: stefanos.xenarios@bioforsk.no

Received 13 June 2012; accepted in revised form 10 July 2013.
}

regional or national level. Rarely is there any consideration given towards the overall impediments that inhibit reducing the cost of drillings in SSA, although significant initiatives are currently underway (Danert and Furey, 2013). Another aspect hardly addressed in the literature is the estimation of the future groundwater expenditures in SSA given the current technological and societal conditions. The absence of systematic cost-related data and the low importance given to groundwater management in SSA have discouraged forecasting analyses of groundwater expenditures (Foster et al., 2011).

This study initially attempts to categorise in a systematic manner all the relevant fixed and variable costs pertaining to groundwater development in selected countries of SSA. Further, a cross-country correlation analysis is used to reveal the potentially significant effects of individual cost factors on the total groundwater costs. In turn, the most important institutional and technical factors that restrain lower-cost drillings in SSA are overviewed. Lastly, a time-series analysis is applied on a country-wise basis for forecasting the groundwater costs over the next decade.

This study focuses on 11 specific Sub-Saharan African countries which were selected within the context of a groundwater research project led by the International Water Management Institute, i.e., Burkina Faso, Mali, Ghana, Kenya, Ethiopia, Mozambique, Niger, Nigeria, Tanzania, Uganda, and Zambia. The data collection was conducted through published reports and grey literature related to the selected countries.

It should be noted that the study focuses only on machine drilling conducted in the selected countries. It is acknowledged that manual and shallow drilling occurs to varying degrees in many of the aforementioned countries, and strong encouragement of such practices is currently underway (Van der Wal et al., 2005; Van Herwijnen, 2005a,b; Strand, 2010, Sutton et al., 
2012). Given the relatively low cost of manual drilling, conducted with semi-skilled labour in a short time, it is a valued alternative to the costly, time-consuming and skill-demanding machine drilling process (Van der Wal, 2010; Vuik et al., 2010). However, the low and often temporal yield of shallow aquifers, combined with the restricted hydrogeological environments in which such techniques can be applied, confines the expansion of manual drilling (Kemper et al., 2003; Titus et al., 2009). To this end, this study considers the machine and deep drilling process to still be the most efficient approach to groundwater extraction and only these drilling practices are examined.

\section{METHODOLOGY}

\section{Value allocation analysis}

It is widely acknowledged that a high variability in the economic assessment of drilling costs is apparent due to the broad social, institutional and hydrogeological characteristics met in each country (Strand, 2010). This study initially attempts to capture the most relevant costs, along with some auxiliary data related to technical parameters that provide a better comprehension of the economic value of drilling, testing and equipping boreholes.

The absence of up-to-date data is a major barrier in mapping the relevant cost factors, as indicated for instance, in the cases of Niger and Mali (Sutton, 2010; Obuobie and Barry, 2011a). Also, the assessment of the economic parameters in each country is often unclear because of the different cost categorisations adopted in each country (Furey and Danert, 2012). Further, a high discrepancy in the information provided for the same countries or even the same regions within a country was frequently noted, which decreases the data reliability. For instance, in the case of Ethiopia and Nigeria, some reports conducted by regional authorities presented more intensive and successful drilling activities than demonstrated by the central government (Ayenew et al., 2005; Adelana, 2010). To this end, we attempted to capture the most up-to-date regional and national data from the following sources:

- Eleven county-level groundwater reports undertaken as part of an IWMI-led research project (IWMI, 2011). These reports provide ready access to existing information which is often limited, dispersed and difficult to access.

- More than 27 up-to-date reports published by the Rural Water Supply Network (RWSN) for the examined countries, which offer concise data about the individual cost factors pertaining to variable and fixed costs. Also, the broader literature on drilling problems and challenges and published guidelines for cost-effective groundwater development published by RWSN were taken into account.

- Relevant national and cross-national studies published by the International Water and Sanitation Centre (IRC) and the associated WASH cost programme were consulted by focusing on the countries of Burkina Faso, Ghana and Mozambique.

- Individual research papers and grey literature focused mainly on a country-specific context.

- Personal contact of the authors with drillers and relevant agencies in the countries of Ethiopia, Kenya and Ghana in the period 2010-2011.

It should be mentioned that most of the studies did not identify the exact number of wells and mean values were presented instead from different regions within a country. However, an attempt was made in our study to associate the cost factors with the current drilling operations at a country level. To this end, information was collected about the drilling enterprises, the rig types and the types of drilling machinery operating in the assessed countries.

The cost data collected from the above sources was partitioned into aggregated fixed and variable costs at a country level. Initially, the mean total fixed costs per well development (FC) were calculated while the deviating values were indicated as below:

$$
F C=S_{m}+M D B_{m}+W D_{m}+W Q_{m}+P P_{o p m}
$$

where:

$S_{m}=$ siting costs; the mean costs required for selecting the site before drilling (i.e., desktop, field assessments).

$M D B_{m}=$ mobilisation/demobilisation costs; the mean costs of moving the construction units to and from the construction site.

$W D_{m}=$ well development costs; the mean costs associated with the operation of the well after drilling. In cases where a pump was installed, the pumping costs related to proper well-functioning are included.

$W Q_{m}=$ water quality costs; the mean costs for testing water quality after the drilling operation.

$P P_{o p m}=$ pump purchasing costs; the mean optional costs of pump purchasing including gear box, fittings, metre, installation, motor protection costs.

In turn, the variable costs of groundwater drilling process per metre of drilling (VC) were estimated as follows:

$$
V C=D_{m}+M C_{m}
$$

where:

$D_{m}=$ drilling costs; the mean cost of drilling, including site clearing and preparation per metre.

$M C_{m}=$ material and casing costs; the mean material costs for drilling, the installation costs of casing and the sand/ gravel pack costs.

Further, the surcharge of failed drilling per metre was also assessed as an additional cost to the groundwater development process. Sometimes, the surcharge costs of unsuccessful drillings are included in the agreement while in other cases an extra cost is accounted against the drilling company in case of failure (Furey and Danert, 2012). Recent studies indicate that the preinclusion of such a surcharge to the drilling agreement would entail more cost-effective groundwater development (Burr and Fonseca, 2013; Danert and Furey, 2013). However, since there is no common practice across SSA yet, we consider this 'failure surcharge' as an additional cost factor. The summation of the fixed, variable costs and the failure surcharge give the total costs per well development on a country level.

It is well known that the added values from taxation and depreciation costs are not always included in studies related to drilling costs. Even in cases where an assessment of these indirect costs is applied, the calculation is frequently obscure (Strand, 2010). However, for the purpose of conducting a levelled cross-country assessment we presumed that the examined studies have considered the indirect cost factors (tax and depreciation), unless clearly stated otherwise. These indirect costs are mainly enclosed within siting, drilling and mobilisation/demobilisation expenses (Foster et al., 2009; Danert et al., 2010b). 
Further, it was initially attempted to capture both the cost and pricing values per drilling but without success. The net revenues which actually mirror the profits - and when added with the costs incurred by the drilling operators determine the price - were hard to capture. Although in some studies of private drillings the profit sharing was transparent, in cases of state or non-governmental organisation funded drillings the profit estimations were not accounted for (Harvey, 2009). To this end, the analysis has only cautiously selected studies where only the cost factors were denoted in the eleven countries.

A set of auxiliary technical data related to the mean values of well depth, diameter and yield was also introduced for a better determination of the cost factors. For a better understanding of the association between the total groundwater development costs and the individual costs factors, a correlation analysis was conducted. The findings identified the cost categories that appear to most influence the sum of the costs in the eleven countries. Further, the most significant technical and institutional factors that constrain machine drilling were reviewed through the collected data.

\section{Forecasting groundwater expenditures}

A time series of yearly data was collected for each country on a per metre basis for the time period 1990-2011. In cases where missing values hindered the data analysis, the time-series was either discarded or replaced with interpolated values where possible (Osborne, 2002). In the cases where interpolated values where used, a higher risk of autocorrelation errors was raised. The potential for autocorrelation effects was examined through the serial dependence, the linear trending and the multicolinearity status amongst the observations (Garson, 2011).

For a better clarification of the actual cost trends in groundwater development, an inflation/deflation adjustment was applied through the Consumer Price Index (CPI). By applying this adjustment to the original series, a more representative trend analysis in real terms is thought to be derived (Nau et al., 1997). The adjustment is usually conducted by dividing monetary time series by the Consumer Price Index (CPI), which is presented in absolute or percentage values
(World Bank, 2010). There are also other adjustment indices in use which offer a better fit to some data but for our case CPI was the only one to have sufficient and reliable data for the examined SSA countries.

The forecasting analysis was applied through AutoRegressive Integrated Moving Average (ARIMA) modeling (Harvey, 2006). The ARIMA modeling was selected due to the lowest autocorrelation predictions presented in each country with regard to other forecasting methods. The ARIMA modeling is comprised of three components: the autoregressive component $(p)$ where the level of autocorrelation is identified; the integrated component $(d)$ where the trend factor is traced; and the moving average component $(q)$ where potential shock events are encountered. In our case, a degree of autocorrelation and trending was noticed which was best confronted by entering the value of 1 in the integrated $(p)$ component. Forecasting was determined for a 9-year period (2012-2020) by taking into consideration the minimum sample size requirement for forecasting in ARIMA models (Hyndman and Kostenko, 2007).

Further, the mean cost difference rate per year is presented for the forecasting period as a comparative indicator of the relevant cost fluctuation on an annual basis. A sensitivity analysis is also conducted for the final forecasting year (2020) in all countries by indicating the maximum and minimum cost per metre of well development based on the deviation from the mean values.

\section{RESULTS AND DISCUSSION}

\section{Technical features and costs}

A description of some key technical data and the aggregated costs of drilling at the country level are presented in Table 1. Drilling depths are greatest in Tanzania, Kenya, Ethiopia and Mali, although the large depth ranges for all four countries imply large differentiations within the country.

The mean drilling diameter is moderately larger in Ethiopia and Mali but not sufficiently high to justify the bigger rigs that are apparently used only for deeper drillings. When examining the mean well yield, countries with relatively shallow wells,

\begin{tabular}{|c|c|c|c|c|c|c|c|c|c|c|}
\hline \multicolumn{11}{|c|}{$\begin{array}{c}\text { TABLE } 1 \\
\text { Technical drilling features and }\end{array}$} \\
\hline Countries & $\begin{array}{l}\text { Depth } \\
\text { (m/well) }\end{array}$ & $\begin{array}{c}\text { Diam. } \\
\text { (inch/well) }\end{array}$ & $\begin{array}{l}\text { Yield } \\
\left(\mathrm{m}^{3} / \mathrm{h}\right)\end{array}$ & $\begin{array}{l}\text { Total costs } \\
\text { (US \$/well) }\end{array}$ & $\begin{array}{c}\text { Variable } \\
\text { costs } \\
\text { (US } \$ / \mathrm{m}) \\
\end{array}$ & \begin{tabular}{|c|} 
Fixed \\
Costs \\
(US \$/well) \\
\end{tabular} & \begin{tabular}{|l|}
$\begin{array}{l}\text { Failed S. } \\
\text { (US } \$ / \mathrm{m} \text { ) }\end{array}$ \\
\end{tabular} & P.T. & $\begin{array}{l}\text { Refe- } \\
\text { rence } \\
\text { year }\end{array}$ & $\begin{array}{l}\text { Literature } \\
\text { source }\end{array}$ \\
\hline Burkina Faso & $60( \pm 6)$ & $5( \pm 1)$ & $5( \pm 4)$ & $12549( \pm 1631)$ & 89 & \begin{tabular}{|l|}
5896 \\
\end{tabular} & 22 & HP & 2012 & NR,IR,WS \\
\hline Ethiopia & $100( \pm 50)$ & $8( \pm 2)$ & $5( \pm 3)$ & $23268( \pm 6980)$ & 142 & 6199 & 28 & $\mathrm{MP}$ & 2009 & NR,IR \\
\hline Ghana & $52( \pm 30)$ & $6( \pm 2)$ & $25( \pm 18)$ & $9465( \pm 2389)$ & 88 & 3058 & 35 & $\mathrm{HP}$ & 2012 & NR, RW,WS \\
\hline Kenya & $80( \pm 49)$ & $6( \pm 1)$ & $5( \pm 3)$ & $20906( \pm 5226)$ & 97 & 9300 & 48 & MP & 2008 & NR, RW, IR \\
\hline Mali & $100( \pm 50)$ & $8( \pm 2)$ & $6( \pm 2)$ & $15462( \pm 3247)$ & 73 & 6371 & 19 & MP & 2009 & RW,IR \\
\hline Tanzania & $75( \pm 33)$ & $6( \pm 1)$ & $11( \pm 7)$ & $16540( \pm 5789)$ & 96 & 7531 & 24 & MP & 2004 & IR \\
\hline Zambia & $60( \pm 24)$ & $6( \pm 1)$ & $15( \pm 4)$ & $6028( \pm 1507)$ & 100 & 3112 & 32 & $\mathrm{HP}$ & 2007 & NR,RW,WS \\
\hline Niger & $50( \pm 40)$ & $6( \pm 1)$ & NIP & $12194( \pm 4878)$ & 175 & 809 & 53 & $\mathrm{HP}$ & 2006 & NR, RW, IR \\
\hline Nigeria & $50( \pm 10)$ & $6( \pm 1)$ & $1.5( \pm 0.8)$ & $6241( \pm 1248)$ & 41 & 2963 & 25 & $\mathrm{HP}$ & 2010 & NR \\
\hline Mozambique & $41( \pm 10)$ & $4( \pm 1)$ & $5( \pm 2)$ & $8672( \pm 2081)$ & 66 & 2600 & 16 & $\mathrm{HP}$ & 2012 & NR, RW, IR,WS \\
\hline Uganda & $65( \pm 20)$ & $5( \pm 1)$ & $6( \pm 2.4)$ & $10476( \pm 2095)$ & 107 & 3539 & 45 & $\mathrm{MP}$ & 2008 & \begin{tabular}{|l|} 
IR \\
\end{tabular} \\
\hline
\end{tabular}

Note: $( \pm m t)=$ the deviation from the mean value is given in same to the category units; Diam. $=$ Drilling diameter; Failed $S .=$ Failed surcharge additional costs for failed drilling attempt per metre; P.T. = Pump Type; MP= Motorized Pump, HP=Hand pump; Reference year = Year in which the data was captured according to the literature; $N R=$ National Report, $R W=R W S N$ Report, IR= Individual country related report; WS = Wash Cost Report; NIP= No information provided due to lack of data. It is noted that the maximum or minimum values in each category are shadowed with greyish colour as also occurs in the following tables. 


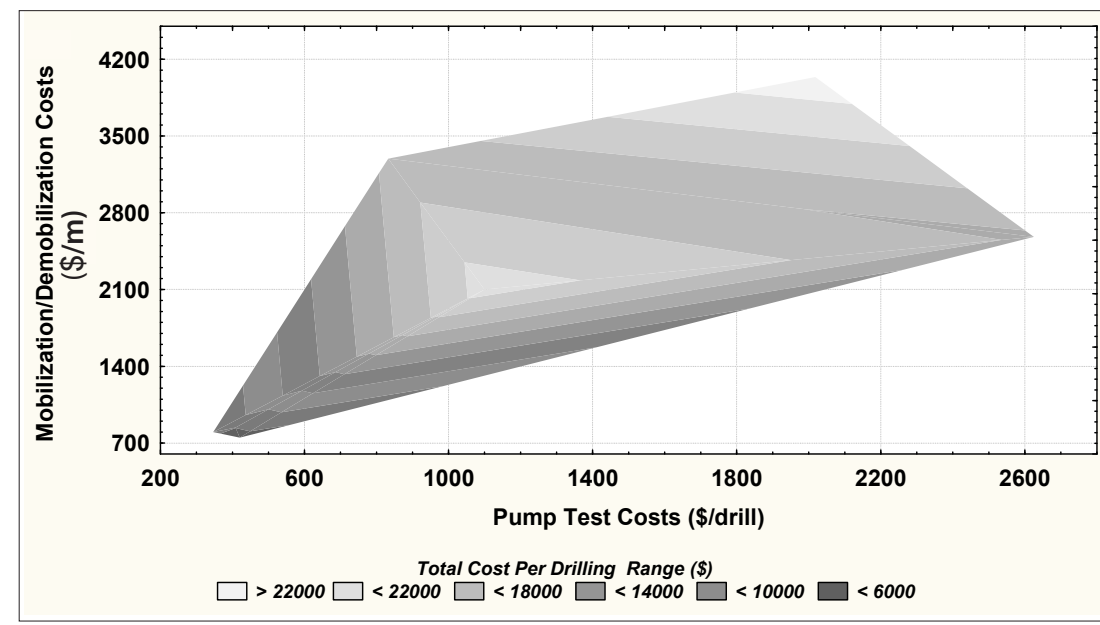

Figure 1

Well development and mobilisation/ demobilisation costs like Ghana, Tanzania and Zambia, seem to offer rather high production rates. This supports the view that the high yields are not merely achieved by deeper drillings but are also highly dependent on the hydrogeological characteristics (Kashaigili, 2010).

In the case of the economic components, the total groundwater costs sum up the fixed costs, which are presented on a per well basis, and the variable with the failed surcharge costs, which are assessed on a per metre basis.

The total costs seem to correlate positively with the average drilling depth in the cases of Tanzania, Kenya, Ethiopia and Mali. In all four cases, motorised pumps (MP), which are rather expensive, seem to be preferred due to the great well depths. Whilst it cannot be assumed that greater well depth equates to greater depth to standing water level; it can be noted that the greater depth provides more scope to draw down the water level in the well and hence the opportunity for MP use. The expensive MP installation, in turn, augments the total groundwater costs in comparison to hand pump (HP) installations where the purchasing costs are distinctively lower.

A noticeable exception occurs in the case of Niger where, although the depths are relatively small $(40-60 \mathrm{~m})$ and cheaper hand pumps are mainly used, the total expenditure is disproportionately high. This confirms the relevant literature which indicates that although the purchasing costs of motorised pumps could be a significant contributor to the total groundwater costs, a multitude of other cost factors could be equally responsible (Wurzel, 2001).

In particular, the high total groundwater costs in Niger seem to be attributed to the high mobilisation/demobilisation costs which are included in variable costs and the surcharges from the failed drilling attempts. Similarly, a sizeable increase is also noticed in the case of Kenya and Uganda for both the aforementioned cost factors, while in the case of Ethiopia a high burden is noticed, mainly in the variable costs. Dissimilarly, in the case of Nigeria the incurred variable costs seem to be distinctively lower than the other countries. It has been suggested that the high divergence between Nigeria and the other countries could in part be explained by the relatively high professional status of the drilling companies, which mitigates against unsuccessful well developments (Adekile, 2012b).

There is an absence of any correlation between depths and variable costs. However, in the case of the fixed groundwater costs, a positive correlation with the drilled depth is observed, except for Niger. The case of Niger is probably attributed to the widespread use of low-cost hand pumps which seems to keep fixed costs down to relatively low levels (Obuobie and Barry, 2011a).

It is also noteworthy that some of the most expensive drillings in Niger, Ethiopia, Kenya and Tanzania exhibit equally high cost ranges. This is possibly due to the greater depth variation at which aquifers are found in these countries, which in turn exacerbates the need for drillers to make use of costlier rigs.

\section{Correlations of groundwater cost factors}

The correlation analysis between the individual variable and fixed cost factors and the total groundwater costs reveals that only the mobilisation/demobilisation $\left(p=0.018, r^{2}=0.83\right)$ and, to a lesser extent, well development costs $\left(p=0.03, r^{2}=0.65\right)$ seem to be positively associated with the total groundwater expenditures at a significant level.

The diagrammatic association of the mobilisation/demobilisation and well development costs with the groundwater expenditures is given in Fig. 1. As presented, there is a high positive correlation between the two individual cost factors, which is reflected in a ratio of about 2:1 among the mobilisation/demobilisation and development costs. If, for instance, US\$ 1000 of development cost expenses were incurred during drilling, a corresponding amount of approximately US $\$ 2000$ of mobilisation/demobilisation costs is additionally required. This relation is also underpinned by recent studies which indicate that exacerbated mobilisation/demobilisation costs mainly occur in remote areas and are usually coupled with higher well development costs in these areas (Foster et al., 2011).

\section{Constraints and drilling operation at a country level}

When the factors that constrain drilling expenditures from being lower are traced, the poor state of the drilling machinery and particularly the aged drilling rigs are commonly referred to in the relevant literature for most of the eleven countries. In particular, the heavy and aged percussion drills which are typically used in Tanzania, Niger, Mali and Kenya (Kashaigili, 2010; Obuobie and Barry, 2011a; Barry and Obuobie, 2011) are quite cumbersome and expensive to transport to remote areas, in comparison to lightweight rigs. When rigs become damaged, repair time is often long, since spare parts can be difficult to source in the market thereby entailing high economic losses to the drillers.

Another aspect that has a direct impact on drilling expenditures is the lack of skilled personnel, especially in terms of hydro-geologists in the drilling teams. The scarcity of 
hydro-geologists is claimed to increase the failure surcharges to an alarming extent (Danert and Furey, 2013).

The lack of technical expertise is also associated with a lack of monitoring and evaluation after the drilling process. There are limited numbers of professionals to monitor any potential damage that emerges after the drilling completion, such as well collapse or groundwater salinization, as reportedly occurs in countries such as Kenya, Uganda and Mali (Hamady, 2011; Ndiritu and Githae, 2011; Sloots, 2010).

These post-drilling damages may sometimes double the initial cost estimates given also the life-span of the borewell. (Foster et al., 2009) However, these cost factors, although rather significant, are beyond the scope of the current study.

The highly variable geology and the long distances between the drilling depot and field site are the next most significant causes of high drilling expenditures. Indicatively, for Burkina Faso, Ghana and Ethiopia the highly divergent geological features seem to trigger the high variable costs (Adekile and Kwei, 2009; Duffau and Ouedraogo, 2009; Obuobie and Barry, 2011b).The distance factor is largely to be blamed for augmented mobilisation/demobilisation costs in all eleven countries and especially for Nigeria and Ethiopia due to the remoteness of inhabited regions (Adekile and Oladobe, 2009; Ethiopian Ministry of Water Resources, 2011).

Further, the tenders for well development, mainly in Zambia, Uganda, Niger and Ethiopia, often refer to a small number of wells, sparsely distributed in remote areas. This inhibits the drilling companies from undertaking sufficient numbers of drilling works in close proximity to effectively minimise the mobilisation/demobilisation costs (Sloots, 2010; Nonde, 2011; Tindimugaya, 2010). A similar situation arises in Nigeria although a lower cost is achieved, which is possibly due to the technological and institutional progress encountered in that country (Adelana, 2010).

The cost of high taxation and the expenditures associated with imported materials are two other significant constraints which are met in all countries and particularly so in Ethiopia and Niger. Finally, the lack of financial capital and access to credit institutions are other noteworthy constraints mainly observed in Tanzania and Burkina Faso (Baumann et al., 2005; Obuobie and Barry, 2011c). Table 2 presents the frequency of the most significant constraints reported in the relevant country literature and in discussions with drilling agencies from Kenya, Ethiopia and Ghana.
It should also be noted that there is a dire need for the registration and licensing of the drilling companies, and the submission of drilling records to responsible government authorities, for better management of groundwater resources (Danert and Furey, 2013). This is however an observation referring to the general situation in SSA, and thus could not be classified as a single country constraint as presented in Table 2.

Further, a preliminary delineation of the current drilling operational activities is presented as distinguished between the type of enterprise, the rig capacity and the machinery used. Unfortunately, the data sources proved to be too incomplete to provide a representative comparison among the countries but may at least enable some insights to be drawn.

In the case of the drilling enterprises, it appears that Ethiopia has a large amount of state-owned companies, although a considerable amount of private enterprises also operate. Nigeria, followed by Uganda and Burkina Faso, seem to be much more dominated by the private sector. In terms of drilling capacity a distinction is made between light $(100-300 \mathrm{~mm})$ and heavyweight $(>300 \mathrm{~mm})$ rigs (Wurzel, 2001). The hydrogeological environment in Ghana seems to encourage the possession of lightweight rigs while the large proportion of highlands in Ethiopia appear to be associated with heavyweight rigs. However, there are also suggestions that heavyweight rigs are mainly used in Ethiopia as well as in Zambia because of the lack of investment in smaller and more appropriate rig sizes (Danert and Furey, 2013). This frequently results in major and unnecessary increase in the drilling costs.

In the case of the drilling construction machinery, Ethiopia seems to be well-equipped with pneumatic hammer rigs, known as 'down-the-hole hammer', which are best suited to the dense-rock conditions of the country. It is believed though that many of these rigs are aged (Mehta and Mehta, 2008). A noticeable number of lightweight percussion and rotary drills are found in Zambia which are in good condition. Quite a few percussion drilling rigs have also recently been purchased by a governmental company in Mozambique which seem to have contributed to lower-cost expenditures (Burr and Fonseca, 2013). Manual drilling machinery seems to mostly be found in Niger which can be in part explained by relatively low depth levels and the alluvial geology that enables manual operations.

\begin{tabular}{|c|c|c|c|c|c|c|}
\hline \multicolumn{7}{|c|}{$\begin{array}{c}\text { TABLE } 2 \\
\text { Institutional and technical constraints }\end{array}$} \\
\hline Countries & $\begin{array}{l}\text { Lack of } \\
\text { skills and } \\
\text { monitoring }\end{array}$ & $\begin{array}{l}\text { Lack of } \\
\text { finance }\end{array}$ & $\begin{array}{c}\text { Variable } \\
\text { geology } \\
\text { and large } \\
\text { distances }\end{array}$ & $\begin{array}{l}\text { High tax-all } \\
\text { imported }\end{array}$ & $\begin{array}{l}\text { Aged drill } \\
\text { - poor } \\
\text { technology }\end{array}$ & $\begin{array}{l}\text { Small contracts - } \\
\text { commissioning }\end{array}$ \\
\hline Burkina Faso & $\mathrm{X}$ & $\mathrm{X}$ & $\mathrm{X}$ & & $\mathrm{X}$ & \\
\hline Ghana & & & $\mathrm{X}$ & & & \\
\hline Mozambique & $\mathrm{X}$ & & & & $\mathrm{X}$ & $\mathrm{X}$ \\
\hline Niger & & & $\mathrm{X}$ & $\mathrm{X}$ & $\mathrm{X}$ & $\mathrm{X}$ \\
\hline Nigeria & & & $\mathrm{X}$ & & & \\
\hline Zambia & $\mathrm{X}$ & & & & $\mathrm{X}$ & $\mathrm{X}$ \\
\hline Uganda & $\mathrm{X}$ & & & & & $\mathrm{X}$ \\
\hline Tanzania & $\mathrm{X}$ & $\mathrm{X}$ & & & $\mathrm{X}$ & \\
\hline Kenya & $\mathrm{X}$ & & $\mathrm{X}$ & $\mathrm{X}$ & $\mathrm{X}$ & \\
\hline Ethiopia & & & $\mathrm{X}$ & $\mathrm{X}$ & $\mathrm{X}$ & \\
\hline Mali & $\mathrm{X}$ & & & & $\mathrm{X}$ & \\
\hline
\end{tabular}




\begin{tabular}{|c|c|c|c|c|c|c|c|c|c|}
\hline \multicolumn{10}{|c|}{$\begin{array}{c}\text { TABLE } 3 \\
\text { Drilling operational activities }\end{array}$} \\
\hline \multirow[t]{2}{*}{ Countries } & \multicolumn{3}{|c|}{ Drilling companies (Nos.) } & \multicolumn{2}{|c|}{$\begin{array}{l}\text { Drilling capacity } \\
\text { (mm/machine) }\end{array}$} & \multicolumn{4}{|c|}{ Drilling construction machinery (Nos.) } \\
\hline & State & Private & NGOs & LW & HW & DTH & Percussion & Rotary & Manual \\
\hline Burkina Faso & NIP & 40 & \multicolumn{7}{|c|}{ NIP } \\
\hline Ethiopia & 10 & 25 & 8 & 17 & 26 & 77 & 18 & 5 & 2 \\
\hline Ghana & 1 & 20 & 5 & 26 & \multirow{3}{*}{ NIP } & 30 & \multirow{3}{*}{ NIP } & \multirow{4}{*}{ NIP } & \multirow{5}{*}{ NIP } \\
\hline Kenya & \multirow{2}{*}{\multicolumn{4}{|c|}{ NIP }} & & \multirow{2}{*}{ NIP } & & & \\
\hline Mali & & & & & & & & & \\
\hline Tanzania & 2 & 4 & 2 & 10 & 10 & 3 & 8 & & \\
\hline Zambia & 1 & 11 & 7 & & & 10 & 25 & 14 & \\
\hline Niger & \multirow{2}{*}{ NIP } & NIP & \multirow{2}{*}{\multicolumn{2}{|c|}{ NIP }} & NIP & \multirow{4}{*}{ NIP } & NIP & \multirow{4}{*}{$\begin{array}{l}\text { NIP } \\
\text { NIP }\end{array}$} & 50 \\
\hline Nigeria & & 100 & & & NIP & & NIT & & \\
\hline Mozambique & 1 & 21 & 5 & 10 & & & 14 & & \\
\hline Uganda & NIP & 42 & 3 & 67 & 10 & & NIP & & \\
\hline
\end{tabular}

Note: State $=$ State-owned drilling companies; Private $=$ Privately-owned drilling companies; $N G O s=$ Non-governmental organisation owned drilling companies; $L W=$ Lightweight rigs $(100-300 \mathrm{~mm}) ; H W=$ Heavyweight rigs $(>300 \mathrm{~mm})$; DTH = Down-the-hole hammer drilling method; Percussion = Percussion drilling method; Manual = Manual drilling method; NIP = No information provided due to lack of data.

\section{Forecasting results}

The forecasting analysis gives an insight into the future groundwater costs for the period 2012-2020 based on past observations from 1990-2011. The ARIMA model of $(1,0,0)$ was applied for the minimisation of autocorrelation effects. For the case of Zambia the large number of missing values prohibited a forecasting analysis.

As presented in Fig. 2, in the case of south-eastern SSA countries, a high fluctuation of the observed values is noticed in all countries except for Uganda. Ethiopia had the highest expenses at the beginning of the 90s although a significant decrease occurred in the following decade which encouraged a downward forecasting slope. Kenya features an overall downward slope for the forecasting years, but with high and consistent oscillation events in the observed period. This could entail a forecasting of lower costs but a rather high uncertainty is also implied.

A much lower fluctuation is noticed in Tanzania where, after a considerable increase between 1994 and 2002, the costs slowly decrease, attributing a stabilised forecasting trend. In the case of Uganda, an initial rise is recorded in the early 1990 s but thereafter costs steadily decrease, offering some good prospects for the forecasting years. Finally, Mozambique shows a dramatic cost decrease in the early 1990s, which is entirely offset by the end of the same decade. However, a relatively even decrease is observed in the last years which in turn suggest a distinct downward forecasting slope.

The west SSA countries seem to have all undergone a sharp cost decrease in the period 1994-1995 which was negated in subsequent years as presented in Fig. 3. On a country basis, Niger, Mali and particularly Burkina Faso exhibit higher initial costs than Ghana and Nigeria. The cost trends seem to however distinctively decline in the last years for Burkina Faso, offering some good decreasing prospects. A slower decline is presented for Mali and Niger, after which the forecast costs seem to stabilise.

The countries of Ghana and Nigeria start with significantly lower initial costs which are followed by continuous downward trends. The observed values infer a rather distinctive downward

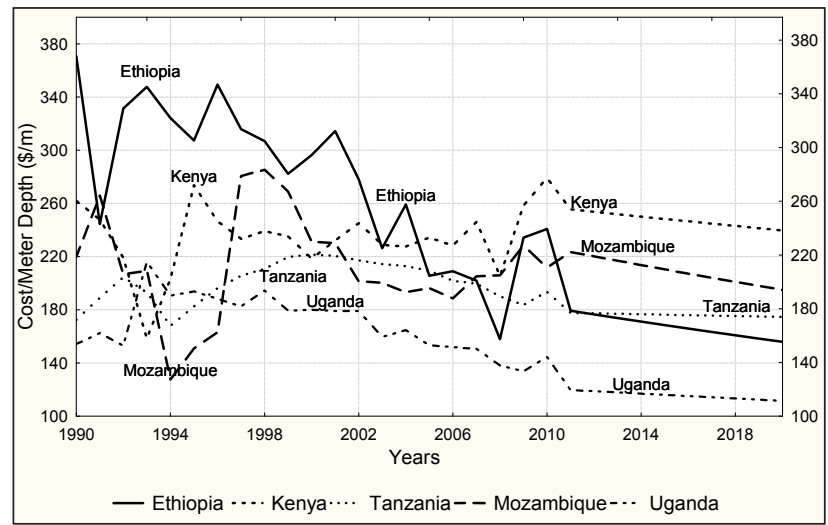

Figure 2

Forecast for south-eastern SSA countries

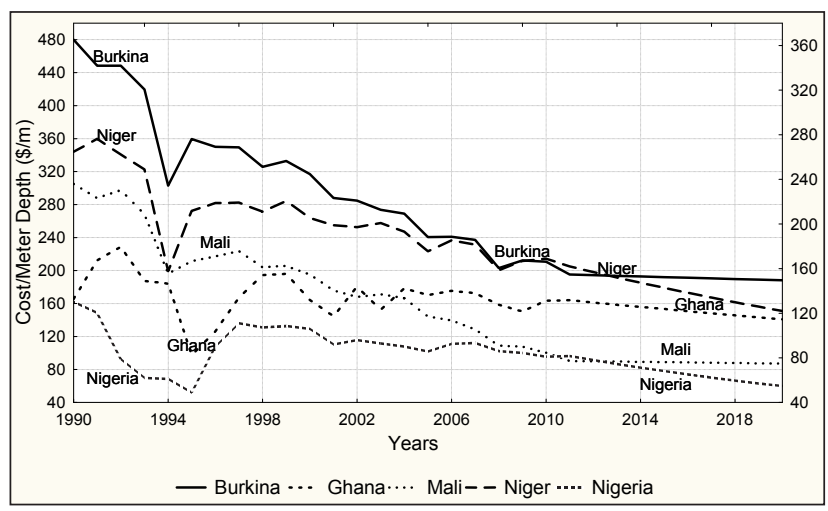

Figure 3

Forecast for west SSA countries

forecast trend for Nigeria while in the case of Ghana a much lower but still noticeable decrease is indicated.

When estimating the mean annual rate difference in Table 4 for the forecasting period 2012-2020 it is observed that Nigeria and Niger have the greatest decreases while in Tanzania the mean rate remains almost stable. South-western 


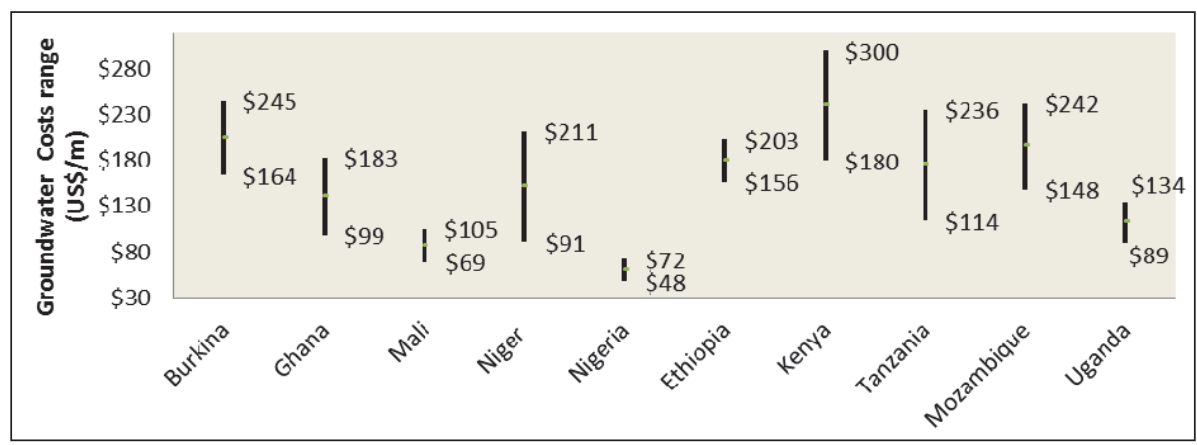

Figure 4

Ranges for groundwater costs for the projected year 2020

\begin{tabular}{|l|c|c|c|c|c|}
\hline \multicolumn{7}{|c|}{ TABLE 4 } \\
\hline Wean annual rate difference for the forecasting period 2012-2020 \\
\hline Rate (\%) & Burkina Faso & Ghana & Mali & Niger & Nigeria \\
\hline East Africa & $0.4 \%$ & $1.7 \%$ & $0.4 \%$ & $3.3 \%$ & $5.2 \%$ \\
\hline Rate (\%) & Ethiopia & Kenya & Tanzania & Mozambique & Uganda \\
\hline
\end{tabular}

SSA countries display further downward trends although the estimates are subject to criticism due to the considerable deviation from the mean rates.

In an attempt to delineate the uncertainty prevailing in the forecast values, a sensitivity analysis was conducted for the final forecasting year 2020 among all the eleven countries. As presented in Fig. 4, Kenya features the highest groundwater costs but with an equally high range, with costs reduced almost by half in some cases. Such a distinctive range is apparent for all of the countries with high groundwater costs, such as Tanzania and Niger. It is also noted that considerable variation occurs for the countries with lower groundwater costs, such as Mali and Nigeria.

\section{CONCLUSION}

This study attempted to systematically categorise groundwater costs as well as to evaluate the significance of individual fixed and variable costs with respect to the total well expenditures across 11 Sub-Saharan African countries. The findings present some interesting cross-country comparisons. It appears that the current groundwater development costs in Ethiopia and Kenya are highest of all SSA countries while the average well yields are not commensurately higher. This is also the case to a lesser extent for Mali and Niger where higher than average costs are not adequately compensated by well yields. Moreover, in the case of Niger, although the fixed costs are the lowest, the low success rate and the increasing mobilisation/demobilisation costs exacerbate the average variable costs.

At a broader level, the mobilisation/demobilisation costs, together with the well development costs, are positively correlated to a high extent and appear to significantly contribute to the increasing groundwater costs at a cross-country level. The constraints are primarily associated with the aged machinery, diverse hydrogeological settings and large distances within the country. Interestingly, the lack of capital as an individual constraint does not appear to be adequately addressed in the literature. It is mostly the lack of knowledge of the existing financial opportunities that discourages drillers from taking investment loans and less so the scarcity of credit from the banking system (Björkman and Svensson, 2007).

The results from the forecasting analysis convey a hopeful indication of a downward or steady groundwater cost trend among all of the examined countries, and most distinctively for Ethiopia, Burkina Faso and Nigeria. It has been noted that the misuse of market principles (Aidt, 2009), the corruption of the regulating authorities, and the poor performance of knowledge dissemination mechanisms still keep groundwater development costs at significantly higher levels than in other developing countries (Kaufmann and Kraay, 2007; Ndiritu, and Githae, 2011). However, it is expected that the drivers of higher competition, upgraded machinery, introduction of free market initiatives and efforts in capacity-building will help to keep the future cost trends downward for all sectors, including the drilling industry (Word Bank, 2010).

Currently, the increasing use of groundwater in SSA is attributed to domestic and agricultural purposes, while more recently the industrial sector has also benefitted through groundwater use (MoWR, 2011; Canuto, 2011). It has been suggested that industry can absorb the high groundwater cost more readily than users of water for irrigation and domestic purposes (Johansson, 2005). Industry could amplify groundwater development by also lowering the cost trends through a prosperous and competitive groundwater market. However, an increase in industrial groundwater use would probably also create competition with irrigation in low-income agrarian regions and with domestic use in rapidly growing urban centres. The irrigation and domestic users are mostly unable to fully compensate for the well development costs but are in a dire need of groundwater in most of the 11 assessed countries. Future groundwater distribution and pricing in the industrial, agricultural and domestic sectors will most likely greatly affect groundwater cost trends in the following years (Tsur, 2005). However, this is a very broad research area which falls beyond the scope of this study.

This study is subject to critical data limitations which in turn question the consistency of the suggested methodology. In principle, the absence of disaggregated cost data in quite a few cases inhibited a detailed cross-country analysis. Also, the data used here is unverified by other independent sources, thereby creating some uncertainty in the accuracy of the results. Further, the widely diverging ranges in groundwater costs can in turn question the value of presenting averages. Finally, the forecasting and sensitivity analyses are still in an early stage and further clarifications are required.

For overcoming the absence of disaggregated cost data, certain technical proxies were introduced (i.e., drilling method, 
rig type, geological formations, etc.) to estimate the individual cost factors. Also, in all of the cases the total groundwater costs have been previously captured and represented the benchmark values for the disaggregation analysis.

Further, it is acknowledged that the use of additional independent sources could potentially enhance the reliability of our results. However, in most of the cases, the data presented in these sources was quite abstract, merely indicating some figures without mentioning the drilling area, the reference year and the technical features (Burr and Fonseca, 2013). It was thus believed that the cross-checking of our selected literature sources enriched by the direct contact with drillers could present more reliable and coherent data.

Also, the widely diverging cost ranges from the disaggregation and sensitivity analysis highlights that there is still insufficient data on a country level and in SSA as a whole. By admitting the data scarcity problem, it is however believed that even the wide-ranging estimates provided here could offer some initial assessment of the groundwater development costs. It is well recognised that the results should be further refined through a thorough technical, institutional and societal assessment at the country level.

In conclusion, it is recommended that increased effort is needed for the collection and analysis of more and better groundwater-related data on the national and regional level. It should be noted that data standardisation and comparison across countries is a rather arduous task with ambivalent results at times. Given these constraints, it is however considered that the current study offers a useful starting point for a meaningful comparison among groundwater development practices, costs and trends across selected Sub-Saharan African countries.

\section{ACKNOWLEDGEMENTS}

The research was undertaken through the project 'Groundwater in Sub-Saharan Africa: Implications for food security and livelihoods' funded by the Rockefeller Foundation (Project No. 2008-AGR-305) and administered through the CGIAR Research Program on Climate Change, Agriculture and Food Security (CCAFS). The authors should also like to deeply thank the anonymous reviewers for their very constructive comments and Dr Kerstin Danert for her helpful comments in the $6^{\text {th }}$ Rural Water Supply Network Forum held in Uganda (2011), where an earlier version of this study was presented.

\section{REFERENCES}

ADAMS S, COBBING J, DENNIS I and RIEMANN K (2012) Groundwater: Our source of security in an uncertain future. Water SA 38 (3) 357-358.

ADEKILE D (2012a) Procurement and Contract Management of Drilled Well Construction: A Guide for Supervisors and Project Managers. Field Note No. 2012-4. Rural Water Supply Network / Skat Foundation, St Gallen, Switzerland.

ADEKILE D (2012b) Supervising Water Well Drilling A Guide for Supervisors. Field Note No. 2012-2. Rural Water Supply Network, St Gallen, Switzerland.

ADEKILE D and KWEI C (2009) The Code of Practice for CostEffective Boreholes in Ghana: Country Status Report. Rural Water Supply Network / Skat Foundation, St Gallen, Switzerland.

ADEKILE D and OLADOBE O (2009) Hand Drilling in Nigeria. Why kill an ant with a sledgehammer? Field Note No 2009-1. Rural Water Supply Network / Skat Foundation, St Gallen, Switzerland.

ADELANA SMA (2010) The hydrogeology and groundwater situation in Nigeria. Country Report prepared for project: 'Groundwater in Sub-Saharan Africa: Implications for food security and livelihoods'. International Water Management Institute, Sri Lanka.

AIDT T (2009) Corruption, institutions, and economic development. Oxford Rev. Econ. Polic. 25 (2) 271-91.

AYENEW T, MASRESHA P and SELESHI BA (2005) Ethiopia. Country Report prepared for project: 'Groundwater in SubSaharan Africa: Implications for food security and livelihoods'. International Water Management Institute, Sri Lanka.

BALL P (2004) Solutions for Reducing Borehole Costs in Rural Africa. Rural Water Supply Network / Skat Foundation, St Gallen, Switzerland.

BARRY B and OBUOBIE E (2011) Status report on groundwater in Mali. Country Report prepared for project: 'Groundwater in SubSaharan Africa: Implications for food security and livelihoods'. International Water Management Institute, Sri Lanka.

AUMANN E, BALL P and BEYENE A (2005) Rationalization of Drilling Operations in Tanzania: Review of the Borehole Drilling Sector in Tanzania. Rural Water Supply Network / Skat Foundation, St Gallen, Switzerland.

BJÖRKMAN M and SVENSSON J (2007) Power to the People: Evidence from a Randomized Field Experiment of a CommunityBased Monitoring Project in Uganda. World Bank Policy Research Working Paper No. 4268. World Bank, Washington, DC.

BURR P and FONSECA C (2013) Applying a life-cycle costs approach to water costs and service levels in rural and small town areas in Andhra Pradesh (India), Burkina Faso, Ghana and Mozambique. Working Paper No. 8. Wash Cost, IRC International Water and Sanitation Centre, The Hague.

CANUTO JA (2011) Cost-effective boreholes in Mozambique: an analysis of practice under the one million initiative 2008-2010. UNICEF, New York.

DANERT K and FUREY S (2013) Groundwater Matters: Drinking Water for Rural People. Four week e-discussion from $10^{\text {th }}$ September 2012. Rural Water Supply Network, St Gallen, Switzerland.

DANERT K, ARMSTRONG T, ADEKILE D, DUFFAU B, OUEDRAOGO I and KWEI C (2010a) Code of Practice for CostEffective Boreholes. Rural Water Supply Network, St Gallen, Switzerland.

DANERT K, LUUTU D and OLSCHEWSKI C (2010b) Costing and Pricing: A Guide for Water Well Drilling Enterprises. Field Note No 2010-6. Rural Water Supply Network / Skat Foundation, St Gallen, Switzerland.

DANERT K (ed.) (2009) Cost Effective Boreholes: Hand Drilling Directory. Rural Water Supply Network / Skat Foundation, St Gallen, Switzerland.

DUFFAU B and OUEDRAOGO I (2009) Burkina Faso: Summary of Findings of 2009 Study and Draft National Code of Conduct. In: Code of Practice for Cost-Effective Boreholes, Rural Water Supply Network / Skat Foundation, St Gallen, Switzerland.

ETHIOPIAN MINISTRY OF WATER RESOURCES (2011) Ethiopia: Strategic Framework for Managed Groundwater Development. Ethiopian Ministry of Water Resources, Addis Ababa.

FONSECA C, FRANCEYS R, BATCHELOR C, McINTYRE P, KLUTSE A, KOMIVES K, MORIARTY P, NAAFS A, KWABENA N, PEZON C, POTTER A, REDDY R and SNEHALATHA M (2011a) Life-cycle costs approach: Costing sustainable services. Briefing Note 1a. Wash Cost, IRC International Water and Sanitation Centre, The Hague.

FONSECA C, DUBE A and VERHOEVEN J (2011b) Cost-based decision support tools for water and sanitation. Working Paper No.4. Wash Cost, IRC International Water and Sanitation Centre, The Hague.

FOSTER S, TOVEY C and TYSON G (eds.) (2011) Groundwater Management and Protection: Progress through World Bank Operations and Beyond during 2000-10. World Bank, Washington, DC.

FOSTER S, PERRY C, HIRATA R and GARDUÑO H (2009) Groundwater Resource Accounting: critical for effective management in a 'changing world'. Briefing Note Series Note 16. The World Bank Development Research Group Environment and Energy Team, Washington, DC. 
FUREY SG and DANERT K (2012) Sustainable Groundwater Development: Use, Protect and Enhance. Publication No. 2012-1. Rural Water Supply Network, St Gallen, Switzerland.

JOHANSSON RC (2005) Pricing Irrigation Water: A Literature Survey. The World Bank, Washington, DC

HAMADY N'DJIM (2011) Water and Population Dynamics: Case studies and Policy Implications. Ministry of Rural Development and Environment, Mali.

HARVEY PA (2009) Cost determination and sustainable financing for rural water services in sub-Saharan Africa. Water Polic. 9 373-391.

HARVEY PA (2006) Chapter 7: Forecasting with Unobserved Components Time Series Models. In: Elliott G, Granger CWJ and Timmermann A (eds.) Handbook of Economic Forecasting, Volume 1. 327-412.

HYNDMAN RJ and KOSTENKO A V (2007) Minimum sample size requirements for seasonal forecasting models. FORESIGHT Issue 6, Spring 2007. 12-15.

GARSON GD (2011) Time Series Analysis. North Carolina State University, Public Administration Program, URL: http://faculty. chass.ncsu.edu/garson/PA765/time.htm (Accessed 11 January 2013).

IWMI (INTERNATIONAL WATER MANAGEMENT INSTITUTE) (2011) Groundwater in Sub-Saharan Africa: Implications for food security and livelihoods. International Water Management Institute, Sri Lanka. URL: http://gw-africa.iwmi.org/ (Accessed 12 March 2011)

KASHAIGILI J (2010) Assessment of groundwater availability and its current and potential use and impacts in Tanzania. Country Report prepared for project: 'Groundwater in Sub-Saharan Africa: Implications for food security and livelihoods'. International Water Management Institute, Sri Lanka.

KAUFMANN D and KRAAY A (2007) Governance Indicators: Where We Are, Where We Should Be Going. Policy Research Working Paper No. 4370. World Bank, Washington, DC.

KEMPER K, FOSTER S, GARDUÑO H, NANNI M and TUINHOF A (2003) Economic Instruments for Groundwater Management: Using Incentives to Improve Sustainability. Briefing Note 7. Groundwater Mate. World Bank, Washington DC.

MEHTA M and MEHTA D (2008) Financing water and sanitation at local levels: Synthesis paper. WaterAid, London.

NAU R, GRØNN E, MACHINA M J and BERGLAND O (eds.) (1997) Economic and Environmental Risk and Uncertainty: New Models and Methods. Series: Theory and Decision Library B, Vol. 35, XII. Springer, Dordrecht. 268 pp.

NONDE A (2011) Zambia. Country Report prepared for project: 'Groundwater in Sub-Saharan Africa: Implications for food security and livelihoods'. International Water Management Institute, Sri Lanka.

NDIRITU PG and GITHAE IT (2011) Kenya. Country Report prepared for project: 'Groundwater in Sub-Saharan Africa: Implications for food security and livelihoods'. International Water Management Institute, Sri Lanka.

TINDIMUGAYA C (2010) Assessment of groundwater availability and its current and potential use and impacts in Uganda. Country Report prepared for project: 'Groundwater in Sub-Saharan Africa: Implications for food security and livelihoods'. International Water Management Institute, Sri Lanka.
OBUOBIE E and BARRY B (2011a) The status of groundwater in Niger. Country Report prepared for project: 'Groundwater in SubSaharan Africa: Implications for food security and livelihoods'. International Water Management Institute, Sri Lanka.

OBUOBIE E and BARRY B (2011b) Ghana Country Status on Groundwater. Country Report prepared for project: 'Groundwater in Sub-Saharan Africa: Implications for food security and livelihoods'. International Water Management Institute, Sri Lanka.

OBUOBIE E and BARRY B (2011c) Groundwater status in Burkina Faso. Country Report prepared for project: 'Groundwater in SubSaharan Africa: Implications for food security and livelihoods'. International Water Management Institute, Sri Lanka.

OSBORNE JW (2002) Notes on the use of data transformations. Practical Assessment, Research, and Evaluation 8 (6) URL: http:// ericae.net/pare/getvn.asp? $\mathrm{v}=8 \& \mathrm{n}=6$ (Accessed 11 January 2011).

SCHNEIDER JS (2012) Water Supply Well: Guidelines for Use in Developing Countries ( $2^{\text {nd }}$ Edition). Rural Water Supply Network / Skat Foundation, St Gallen, Switzerland.

SLOOTS R (2010) Assessment of Groundwater Investigations and Borehole Drilling Capacity in Uganda. The Republic of Uganda Ministry of Water and Environment /UNICEF, New York.

STRAND J (2010) The Full Economic Cost of Groundwater Extraction. Policy Research Working Paper 5494m. The World Bank Development Research Group Environment and Energy Team, Washington, DC.

SUTTON S, BUTTERWORTH S and MEKONTA L (2012) A Hidden Resource: Household-Led Rural Water Supply in Ethiopia. IRC International Water and Sanitation Centre, The Netherlands.

SUTTON S (2010) Accelerating Self Supply, A Case Study from Mali 2010. Field Note No. 2010-1. Rural Water Supply Network Secretariat, St Gallen, Switzerland.

TITUS R, BEEKMAN H, ADAMS S and STRACHAN L (ed.) (2009) The Basement Aquifers of Southern Africa. WRC Report No. TT 428-09. Water Research Commission, Pretoria.

TSUR Y (2005) Economic aspects of irrigation water pricing. Can. Water Resour. J. 30 (1) 31-46.

VAN DER WAL A, HOLTSLAG H and DE JONG J (2005) Rope Pump Manual, Ethiopia, Hand Dug Well \& Borehole Model. Practica Foundation, The Hague, The Netherlands.

VAN DER WAL A (2010) Understanding Groundwater \& Wells in Manual Drilling: Instruction Handbook for Manual Drilling Teams on Hydro-Geology for Well Drilling, Well Installation and Well Development. Practica Foundation, The Hague, The Netherlands.

VAN HERWIJNEN A (2005A) Rota Sludge and Stone Hammer Drilling - Part 1 Drilling Manual. Practica Foundation and ETC Energy, Delft, The Netherlands.

VAN HERWIJNEN A (2005B) Rota Sludge and Stone Hammer Drilling - Part 2 Production Manual. Practica Foundation and ETC Energy, Delft, The Netherlands.

VUIK R, DE KONING D and VAN DER WAL A (2010) Manual Drilling Series: Jetting. Practica Foundation, The Hague, The Netherlands.

WORLD BANK (2010) Africa Development Indicators 2010, The Little Data Book on Africa 2010. World Bank, Washington, DC.

WURZEL P (2001) Drilling Boreholes for Handpumps. Swiss Centre for Development Cooperation in Technology and Management. ITDG Publishing, London. 
http://dx.doi.org/10.4314/wsa.v39i4.12 Available on website http://www.wrc.org.za

ISSN 0378-4738 (Print) $=$ Water SA Vol. 39 No. 4 July 2013 ISSN 1816-7950 (On-line) = Water SA Vol. 39 No. 4 July 2013 